Article

\title{
Dietary Sodium Intake and Food Sources among Chinese Adults: Data from the CNNHS 2010-2012
}

\author{
Kehong Fang, Yuna He *, Yuehui Fang and Yiyao Lian $\mathbb{D}$
}

National Institute for Nutrition and Health, Chinese Center for Disease Control and Prevention, No. 29 Nanwei Road, Xicheng District, Beijing 100050, China; kehongsky@163.com (K.F.); fangyh@ninh.chinacdc.cn (Y.F.); lian_yiyao@163.com (Y.L.)

* Correspondence: heyn@ninh.chinacdc.cn; Tel.: +86-010-67791292

Received: 20 December 2019; Accepted: 5 February 2020; Published: 11 February 2020

\begin{abstract}
The present study was done to examine the status of dietary sodium intake and dietary sources of sodium among Chinese adults. Data were obtained from China National Nutrition and Health Surveillance (CNNHS) 2010-2012. All adults recruited in this study provided complete dietary data on three-day consecutive 24-h dietary recalls combining with the household weighing method. Sodium intake was adjusted for energy to $2000 \mathrm{kcal} /$ day using the residual method. Average sodium intake was 5013 (95\% Confidence Interval, CI: 4858, 5168) mg/day, and 92.6\% of adults' sodium intake exceeded the standard in the Chinese proposed intake for preventing non-communicable chronic diseases (PI-NCD). The salt added to food was the main contributor to daily sodium intake, representing $69.2 \%$ of the total sodium consumption. The proportion of sodium from salt was different in some subgroups. The contribution ranged from $64.8 \%$ for those who came from urban areas aged $18-49$ years old to $74.7 \%$ for those who came from rural areas with education levels of primary school or less, and sodium from soy sauce was the next highest contributor ( $8.2 \%)$. The proportion of the subjects with sodium intake contributed by flour products was higher in the north with $7.1 \%$ than the south with $1.4 \%$. The average consumption of sodium among Chinese was more than the recommended amount, and salt was the main source of sodium.
\end{abstract}

Keywords: sodium; salt; dietary; Chinese

\section{Introduction}

The sodium intake recommended by The World Health Organization (WHO) is below $2000 \mathrm{mg} /$ day to prevent chronic disease [1]; however, only a few countries have a daily dietary sodium consumption that does not exceed the recommended level around the world [2]. Overconsumption of dietary sodium is the top risk factor for cardiovascular diseases, such as hypertension, stroke and heart failure [3-7] which are the major causes of death and disability in China and the rest of the world [8,9]. In China, high sodium intake is the leading dietary risk factor for cardiometabolic mortality and was associated with a population attributable fraction (PAF) of $17.3 \%$ in 2010 [10]. The global burden of disease (GBD) study also showed that 3 million people died from overconsumption of sodium in 2017 around the world [11]. Overconsumption of sodium is one of the most important factors affecting the global burden of disease. Thus, some countries regard sodium intake as a major public health concern.

Some countries have developed strategies to limit sodium intake to meet the recommended consumption set by WHO [12-15]. Because the lack of knowledge on dietary sodium intake as well as food sources are major obstacles in controlling sodium consumption, some surveys were conducted to estimate the sodium intake and source of sodium in adults with different dietary habits. For example, the consumption of sodium in the United Kingdom and Japan is $3406 \mathrm{mg} /$ day and $4651 \mathrm{mg} /$ day, respectively. The majority of sodium comes from processed foods $(95 \%)$ in the United Kingdom, 
and the contribution of soy sauce and salted food to daily sodium intake is about 63\% in Japan [16]. However, there is scarce information about the status of dietary sodium intake and dietary sources of sodium in China, and sodium consumption by the Chinese is also different from that in other countries due to the different dietary structures $[13,17]$. Therefore, understanding sodium consumption and the sources of dietary sodium among Chinese people would be helpful in developing preventive strategies to reduce sodium intake.

\section{Materials and Methods}

\subsection{Study Population}

This cross-sectional analysis was based on data from the China National Nutrition and Health Surveillance (CNNHS). The CNNHS was carried out on a stratified, multistage, systematic, clustered, and random sampling method, proportional to the population, to form a representative sample of China as a whole, including 31 provinces (excluding Hong Kong, Macao, and Taiwan). Firstly, according to the level of economic development, administrative units at the county level in China are divided into four categories: large cities, small and medium-sized cities, ordinary rural areas, and poor rural areas. In the end, 150 monitoring sites were selected in China, including 34 large cities, 41 small and medium-sized cities, 45 ordinary rural areas and 30 poor rural areas; secondly, according to the composition ratio of urban and rural populations in the selected monitoring sites, 6 residential (village) committees were selected from each monitoring site, and 75 households were selected from the selected residential (village) committees by a simple random sampling method, 30 of which were dietary survey households. The survey was approved by the Ethical Committee of the National Institute for Nutrition and Food Safety at the Chinese Center for Disease Control and Prevention (2013(018)) [18].

\subsection{Estimating Total Sodium Intake}

The questionnaire was designed to collect information about socio-demographics, diet, health, and lifestyle status. Well-trained dietary staff collected individual dietary sodium intake over a consecutive three-day, 24-h dietary recall combined with a household food weighing method (including two weekdays and one weekend day). The amount of edible oil and ingredients (such as salt, soy sauce, chicken essence, and other condiments) used at home were measured by a uniformly calibrated electronic scale. Dietary sodium intake from each food was calculated according to the Chinese Food Composition Table [19], and the food not included in the table was grouped into the most similar categories. The Chinese proposed intakes for preventing non-communicable chronic diseases (PI-NCD) cut-point was used to estimate the population prevalence of excess intake. The overconsumption of PI-NCD sodium was defined as dietary sodium $\geq 2000 \mathrm{mg} /$ day for 18 to 49 years old, $\geq 1900 \mathrm{mg} /$ day for 50 to 64 years old, or $\geq 1800 \mathrm{mg} /$ day for 65 years old and over [20]. The sodium intake recommended by The World Health Organization (WHO) is below $2000 \mathrm{mg} /$ day [1]. Sodium intake was adjusted for energy to $2000 \mathrm{kcal} /$ day using the residual method [21].

\subsection{Statistical Analysis}

All analyses were carried out with SAS 9.4 (SAS Institute, Cary, NC, USA). Applying the post-stratification population sampling weights derived for the dietary surveys from the sampling probability of the 2010 Chinese population aged 18 years or older (based on census data), we estimated the nationally representative population levels for intake of food and nutrients. Data are expressed as mean (95\% CI) and weighted percent, and differences between groups were analysed using survey means or weighted percentages for survey design. A $p$ value $<0.05$ was considered to be statistically significant. 


\section{Results}

\subsection{Study Population Characteristics}

The CNNHS recruited 53,993 adults with complete dietary intake data (Table 1), 25,309 (46.9\%) of whom were 18-49 years old, 18,320 (33.9\%) were 50-64 years old, and 10,364 (19.2\%) were 65 years old and over. Males accounted for 24,777 (45.9\%), and 25,212 (46.7\%) of subjects were from the north, $26,782(49.6 \%)$ of whom were urban subjects and $27,211(50.4 \%)$ were rural subjects.

Table 1. Demographic characteristics of the 53,993 adults.

\begin{tabular}{lccc}
\hline & Total Sample, $\boldsymbol{n} \mathbf{( \% )}$ & Urban, $\boldsymbol{n}(\mathbf{\%})$ & Rural, $\boldsymbol{n} \mathbf{( \% )}$ \\
\hline Age (years) & & & \\
$18-49$ & $25,309(46.9)$ & $11,393(42.5)$ & $13,916(51.1)$ \\
$50-64$ & $18,320(33.9)$ & $9573(35.7)$ & $8747(32.2)$ \\
$\geq 65$ & $10,364(19.2)$ & $5816(21.7)$ & $4548(16.7)$ \\
\hline Gender & & & \\
$\quad$ Male & $24,777(45.9)$ & $12,053(45.0)$ & $12,724(46.8)$ \\
Female & $29,216(54.1)$ & $14,729(55.0)$ & $14,487(53.2)$ \\
\hline Geographic region * & & & \\
$\quad$ South & $28,781(53.3)$ & $14,860(55.5)$ & $13,921(51.2)$ \\
$\quad$ North & $25,212(46.7)$ & $11,922(44.5)$ & $13,290(48.8)$ \\
\hline Highest level of education & & & \\
$\quad$ Primary school or less & $22,226(41.2)$ & $7355(27.5)$ & $14,871(54.7)$ \\
$\quad$ Middle school & $27,145(50.3)$ & $15,257(57.0)$ & $11,888(43.7)$ \\
$\quad$ College and above & $4621(8.6)$ & $4170(15.6)$ & $451(1.7)$ \\
\hline
\end{tabular}

\subsection{Dietary Sodium Intakes of the Subjects}

The average sodium consumption was 5013 (95\% CI: 4858, 5168) mg/day for the study adults, and there was a higher consumption among urban $(5060 \mathrm{mg} / \mathrm{day})$ compared with rural (4966 mg/day) adults. Urban adults in the south consumed more sodium (mean $=4925 \mathrm{mg} / \mathrm{day}, 95 \%$ CI: 4736, 5114) than rural adults (mean $=4408 \mathrm{mg} /$ day, 95\% CI: 4100, 4717). On the contrary, the urban adults in the north (mean $=5238 \mathrm{mg} /$ day, 95\% CI: 4931, 5544) consumed less sodium than rural adults $($ mean $=5544 \mathrm{mg} / \mathrm{day}, 95 \% \mathrm{CI}: 5210,5877)$. The medians of sodium intake were higher than the specific PI-NCD for each respective age group, and the records were $4439 \mathrm{mg}$ /day in 18-49 years old, $4702 \mathrm{mg} /$ day in 50-64 years old, and $4488 \mathrm{mg} /$ day in over 65 years old. The prevalence of sodium intake above PI-NCD among all adults included in the study was $92.6 \%$ (Table 2).

\subsection{Proportion of Dietary Sodium from Various Sources}

For the total sample, salt added by individuals when cooking/preparing a meal was the leading source of sodium, accounting for $69.2 \%$. Soy sauce was the next highest contributor $(8.2 \%)$, followed by processed food $(6.0 \%)$ and chicken essence $(4.5 \%)$. The proportion of sodium contributed by salt increased as age increased in both urban and rural subjects. On the contrary, the proportion of sodium from processed food decreased as age increased in both urban and rural subjects. Sodium contributed by processed food $(7.7 \%)$ was a higher proportion of total sodium intake in the urban adults compared to the rural adults (4.3\%), and the urban adults aged 18-49 years old obtained a higher proportion of sodium from processed food (8.1\%) compared with the rural adults aged 18-49 years old (4.4\%). Subjects from the north $(7.1 \%)$ consumed a greater proportion of sodium from flour products compared with subjects in the south (1.4\%) (Table 3, Figure 1). 
Table 2. Usual dietary intake and the prevalence of excess intake of sodium (mg/day).

\begin{tabular}{|c|c|c|c|c|c|c|c|c|c|c|c|c|}
\hline & \multicolumn{4}{|c|}{ Urban } & \multicolumn{4}{|c|}{ Rural } & \multicolumn{4}{|c|}{ Total } \\
\hline & $\begin{array}{l}\text { Mean (95\% } \\
\text { CI) }\end{array}$ & $\begin{array}{c}\text { Median (p25, } \\
\text { p75) }\end{array}$ & $\begin{array}{c}\text { Over } \\
\left.\text { PI-NCD }{ }^{*} \%\right)\end{array}$ & $\begin{array}{c}\text { Over WHO } \\
\text { Standard (\%) }\end{array}$ & $\begin{array}{l}\text { Mean }(95 \% \\
\text { CI) }\end{array}$ & $\begin{array}{c}\text { Median (p25, } \\
\text { p75) }\end{array}$ & $\begin{array}{c}\text { Over } \\
\text { PI-NCD (\%) }\end{array}$ & $\begin{array}{c}\text { Over WHO } \\
\text { Standard (\%) }\end{array}$ & $\begin{array}{c}\text { Mean }(95 \% \\
\text { CI) } \\
\end{array}$ & $\begin{array}{c}\text { Median (p25, } \\
\text { p75) }\end{array}$ & $\begin{array}{c}\text { Over } \\
\text { PI-NCD (\%) }\end{array}$ & $\begin{array}{c}\text { Over WHO } \\
\text { Standard (\%) }\end{array}$ \\
\hline & $\begin{array}{c}5056 \text { (4887, } \\
5232)\end{array}$ & $\begin{array}{c}4563(3418 \\
6153) \\
\end{array}$ & 92.0 & 91.4 & $\begin{array}{c}4966(4705 \\
5228) \\
\end{array}$ & $\begin{array}{c}4435(2977 \\
6296)\end{array}$ & 93.1 & 92.6 & $\begin{array}{c}5013(4858 \\
5168) \\
\end{array}$ & $\begin{array}{c}4505(3219 \\
6211)\end{array}$ & 92.6 & 92.0 \\
\hline \multicolumn{13}{|l|}{ Age (years) } \\
\hline $18-49$ & $\begin{array}{c}4994(4814 \\
5174)\end{array}$ & $\begin{array}{c}4521(3377 \\
6094)\end{array}$ & $91.2^{\mathrm{a}}$ & $91.2^{\mathrm{b}}$ & $\begin{array}{c}4872(4592, \\
5152)\end{array}$ & $\begin{array}{c}4329(2869 \\
6193)\end{array}$ & $92.6^{\mathrm{a}}$ & $92.6^{\mathrm{b}}$ & $\begin{array}{c}4931(4763 \\
5099)\end{array}$ & $\begin{array}{c}4439 \text { (3140 } \\
6151)\end{array}$ & $91.9^{\mathrm{a}}$ & $91.9^{\mathrm{b}}$ \\
\hline $50-64$ & $\begin{array}{c}5276(5072 \\
5480)\end{array}$ & $\begin{array}{c}4704(3548 \\
6327)\end{array}$ & 94.0 & 92.9 & $\begin{array}{c}5239(4962 \\
5516)\end{array}$ & $\begin{array}{l}4691 \text { (3199, } \\
6595)\end{array}$ & 95.1 & 94.1 & $\begin{array}{c}5259(5093 \\
5426)\end{array}$ & $\begin{array}{c}4702(3404 \\
6456)\end{array}$ & 94.5 & 93.4 \\
\hline$\geq 65$ & $\begin{array}{c}4959(4793 \\
5125) \\
\end{array}$ & $\begin{array}{c}4462(3374 \\
5958) \\
\end{array}$ & 92.3 & 89.1 & $\begin{array}{c}5058(4838 \\
5279) \\
\end{array}$ & $\begin{array}{c}4506(3207 \\
6228)\end{array}$ & 92.2 & 89.8 & $\begin{array}{c}5007(4871, \\
5144)\end{array}$ & $\begin{array}{c}4488(3302 \\
6086)\end{array}$ & 92.2 & 89.5 \\
\hline \multicolumn{13}{|l|}{ Gender } \\
\hline Male & $\begin{array}{c}5143(4945, \\
5341)\end{array}$ & $\begin{array}{c}4637(3426 \\
6330)\end{array}$ & $93.7^{\mathrm{a}}$ & $93.2^{\mathrm{b}}$ & $\begin{array}{c}5061(4773, \\
5349)\end{array}$ & $\begin{array}{c}4533(2943 \\
6495)\end{array}$ & $94.5^{\mathrm{a}}$ & $94.1^{\mathrm{b}}$ & $\begin{array}{c}5102(4928, \\
5275)\end{array}$ & $\begin{array}{l}4601 \text { (3215, } \\
6402)\end{array}$ & $94.1^{\mathrm{a}}$ & $93.7^{\mathrm{b}}$ \\
\hline Female & $\begin{array}{c}4975(4821 \\
5129)\end{array}$ & $\begin{array}{c}4480(3410, \\
5957)\end{array}$ & 90.3 & 89.6 & $\begin{array}{c}8688(4626 \\
5110)\end{array}$ & $\begin{array}{c}4343(3008 \\
6045)\end{array}$ & 91.7 & 91.1 & $\begin{array}{l}4922(4780, \\
5063)\end{array}$ & $\begin{array}{c}4422(3224 \\
5994)\end{array}$ & 91.0 & 90.3 \\
\hline \multicolumn{13}{|l|}{$\begin{array}{l}\text { Geographic } \\
\text { region }\end{array}$} \\
\hline South & $\begin{array}{c}4925(4736 \\
5114)\end{array}$ & $\begin{array}{c}4437(3395 \\
5876)\end{array}$ & 92.2 & 91.6 & $\begin{array}{c}4408(4100 \\
4717)\end{array}$ & $\begin{array}{c}3984(2619 \\
5616)\end{array}$ & 93.0 & 92.5 & $\begin{array}{c}4681(4506 \\
4857)\end{array}$ & $\begin{array}{c}4245(3029, \\
5768)\end{array}$ & 92.5 & 92.0 \\
\hline North & $\begin{array}{c}5238(4931 \\
5544)\end{array}$ & $\begin{array}{c}4717(3463 \\
6449)\end{array}$ & 91.9 & 91.2 & $\begin{array}{l}5544(5210 \\
5877)\end{array}$ & $\begin{array}{c}4939(3447 \\
6972)\end{array}$ & 93.2 & 92.8 & $\begin{array}{c}5400(5176 \\
5625)\end{array}$ & $\begin{array}{c}4833(3454 \\
6704)\end{array}$ & 92.6 & 92.1 \\
\hline \multicolumn{13}{|l|}{$\begin{array}{l}\text { Highest level of } \\
\text { education }\end{array}$} \\
\hline $\begin{array}{l}\text { Primary school } \\
\text { or less }\end{array}$ & $\begin{array}{c}5223(5022, \\
5424)\end{array}$ & $\begin{array}{c}4687(3526 \\
6327)\end{array}$ & $92.3^{\mathrm{a}}$ & $90.9^{\mathrm{b}}$ & $\begin{array}{c}5063(4796 \\
5330)\end{array}$ & $\begin{array}{c}4482(3058 \\
6389)\end{array}$ & 92.8 & 92.0 & $\begin{array}{c}5118(4933, \\
5303)\end{array}$ & $\begin{array}{l}4562(3240 \\
\quad 6371)\end{array}$ & $92.6^{\mathrm{a}}$ & $91.6^{\mathrm{b}}$ \\
\hline Middle school & $\begin{array}{c}5047(4854 \\
5240)\end{array}$ & $\begin{array}{c}4554 \text { (3418, } \\
6144)\end{array}$ & 92.5 & 92.0 & $\begin{array}{c}4897(4614 \\
5180)\end{array}$ & $\begin{array}{c}4407(2925 \\
6223)\end{array}$ & 93.5 & 93.3 & $\begin{array}{c}4977 \text { (4811 } \\
5143)\end{array}$ & $\begin{array}{c}4495 \text { (3215, } \\
6175)\end{array}$ & 93.0 & 92.6 \\
\hline $\begin{array}{l}\text { College and } \\
\text { above }\end{array}$ & $\begin{array}{c}4871(4668 \\
5073)\end{array}$ & $\begin{array}{c}4407(3258 \\
5853)\end{array}$ & 89.8 & 89.7 & $\begin{array}{l}4808(4391 \\
5226)\end{array}$ & $\begin{array}{l}4099 \text { (2840 } \\
6019)\end{array}$ & 91.2 & 91.0 & $\begin{array}{c}4860 \text { (4679, } \\
5042)\end{array}$ & $\begin{array}{c}4368(3203 \\
5903)\end{array}$ & 90.1 & 89.9 \\
\hline
\end{tabular}


Table 3. Proportion contribution of the main food groups to total dietary sodium (\%).

\begin{tabular}{|c|c|c|c|c|c|c|c|c|c|c|c|}
\hline & & & Salt & Soy Sauce & $\begin{array}{l}\text { Processed } \\
\text { Food }\end{array}$ & $\begin{array}{l}\text { Chicken } \\
\text { Essence }\end{array}$ & $\begin{array}{l}\text { Animal } \\
\text { Food * }\end{array}$ & $\begin{array}{c}\text { Flour } \\
\text { Products }\end{array}$ & $\begin{array}{l}\text { Vegetables } \\
\text { and Fruits }\end{array}$ & $\begin{array}{c}\text { Other } \\
\text { Condiments }\end{array}$ & Others ** \\
\hline \multicolumn{12}{|l|}{ Urban } \\
\hline & \multirow[t]{2}{*}{ Gender } & Male & 65.1 & 9.3 & 7.7 & 4.9 & 4.0 & 4.0 & 2.6 & 0.8 & 1.5 \\
\hline & & Female & 65.6 & 9.0 & 7.8 & 4.8 & 4.1 & 3.5 & 2.8 & 0.8 & 1.5 \\
\hline & \multirow[t]{3}{*}{ Age (years) } & $18-49$ & 64.8 & 9.3 & 8.1 & 4.7 & 4.2 & 3.9 & 2.7 & 0.8 & $\begin{array}{l}1.0 \\
1.5\end{array}$ \\
\hline & & $50-54$ & 66.4 & 9.0 & 7.0 & 5.1 & 3.8 & 3.7 & 2.7 & 0.8 & 1.5 \\
\hline & & $\geq 65$ & 66.6 & 8.7 & 6.9 & 5.2 & 4.0 & 3.6 & 2.9 & 0.8 & 1.3 \\
\hline & \multirow{2}{*}{$\begin{array}{l}\text { Geographic } \\
\text { region }\end{array}$} & South & 65.2 & 9.6 & 7.5 & 5.6 & 4.8 & 1.4 & 3.4 & 0.9 & 1.6 \\
\hline & & North & 65.5 & 8.6 & 8.0 & 3.8 & 3.2 & 7.0 & 1.8 & 0.6 & 1.4 \\
\hline & \multirow[t]{3}{*}{$\begin{array}{l}\text { Highest } \\
\text { level of } \\
\text { education }\end{array}$} & $\begin{array}{l}\text { Primary school or } \\
\text { less }\end{array}$ & 68.6 & 8.0 & 6.8 & 5.1 & 3.3 & 3.3 & 2.7 & 0.8 & 1.3 \\
\hline & & Middle school & 65.1 & 9.3 & 7.8 & 4.8 & 4.1 & 4.0 & 2.7 & 0.8 & 1.5 \\
\hline & & College and above & 65.6 & 9.0 & 8.7 & 4.5 & 5.3 & 3.9 & 2.7 & 0.6 & 1.7 \\
\hline \multicolumn{12}{|l|}{ Rural } \\
\hline & \multirow[t]{2}{*}{ Gender } & Male & 72.9 & 7.3 & 4.2 & 4.2 & 2.4 & 4.3 & 2.0 & 1.4 & 1.1 \\
\hline & & Female & 73.0 & 7.3 & 4.4 & 4.2 & 2.5 & 4.1 & 2.2 & 1.3 & 1.1 \\
\hline & \multirow{2}{*}{ Age (years) } & $50-54$ & 74.2 & 7.1 & 4.1 & 4.0 & 2.2 & 3.9 & 2.0 & $\begin{array}{l}1.4 \\
1.4\end{array}$ & 1.0 \\
\hline & & $\geq 65$ & 74.7 & 7.1 & 4.1 & 3.6 & 2.4 & 3.9 & 2.1 & 1.2 & 1.0 \\
\hline & \multirow{2}{*}{$\begin{array}{l}\text { Geographic } \\
\text { region }\end{array}$} & South & 73.5 & 6.8 & 4.0 & 5.5 & 3.1 & 1.4 & 2.7 & 1.8 & 1.2 \\
\hline & & North & 72.4 & 7.8 & 4.7 & 2.9 & 1.7 & 7.1 & 1.4 & 0.9 & 1.0 \\
\hline & \multirow[t]{3}{*}{$\begin{array}{l}\text { Highest } \\
\text { level of } \\
\text { education }\end{array}$} & $\begin{array}{l}\text { Primary school or } \\
\text { less }\end{array}$ & 74.7 & 6.6 & 3.9 & 4.1 & 2.2 & 4.0 & 2.1 & 1.4 & 1.0 \\
\hline & & Middle school & 71.7 & 7.7 & 4.6 & 4.3 & 2.6 & 4.4 & 2.1 & 1.3 & 1.1 \\
\hline & & College and above & 69.6 & 8.7 & 5.4 & 4.3 & 3.3 & 3.7 & 2.2 & 1.7 & 1.2 \\
\hline
\end{tabular}

* Animal food: including red meat and products, poultry and game, eggs, dairy, fish and shrimp. ${ }^{* *}$ Others: including rice, potatoes, soybean and soybean products, and edible oil. 


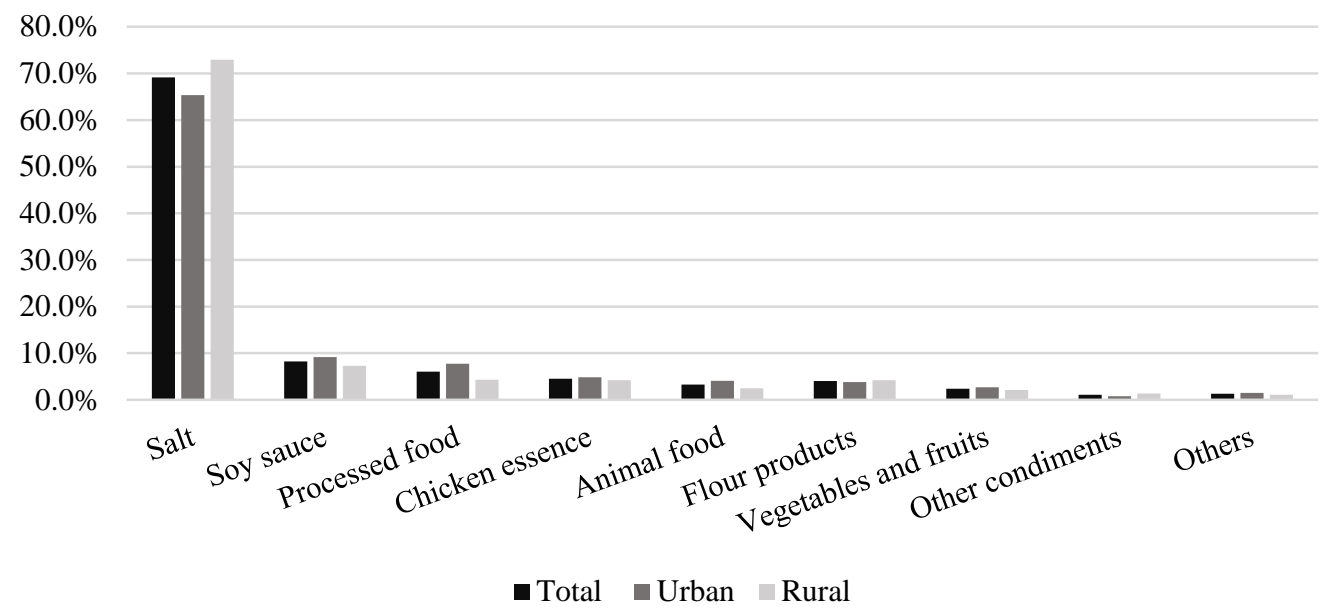

Figure 1. Proportion of sodium intake from various sources.

\section{Discussion}

To our knowledge, this is the first study to describe, in detail, the dietary sodium intake, estimate the dietary sodium sources, and determine the prevalence of overconsumption among Chinese adults. Unlike previous studies $[10,16,22]$, we observed sodium consumption among a wide range of adults. The sodium intake in rural subjects was higher than in urban subjects, and subjects from the north had a higher consumption level compared to subjects from the south. Otherwise, according to this study, the average intake of dietary sodium in Chinese was far in excess of the PI-NCD and the recommended level set by $\mathrm{WHO}$, and salt was the main source of sodium among all recruited adults.

The sodium intake of recruited adults (5013 mg/day) was higher than the overall world average (4000 mg/day) and even exceeded the maximum recommended amount of sodium consumption by 90\% and more [23]. Previous research, which consisted of a sample of Chinese adults $(n=6072)$ has already shown a concerning excessive sodium intake and an average consumption of sodium of $5.4 \mathrm{~g} /$ day [22]. Sodium maintains blood pressure, while consuming an excessive amount of sodium increases the risk of hypertension and NCD $[4,24,25]$. Although a recent study has shown that sodium consumption has been declining since 1982 in China [10], there are still some gaps comparing with the recommendations of the WHO [1]. Since salt added to food is the main source of dietary sodium, controlling salt intake is an important measure to reduce dietary sodium. In addition, further measures are needed to regularly limit and monitor salt/sodium intake. [22].

Sources of dietary sodium vary among countries. In Japan, the mean consumption of sodium is $4651 \mathrm{mg} /$ day, and more than half of the sodium intake (63.2\%) is obtained from soy sauce (34.6\%), meats and eggs (20.4\%), and vegetables and fruits (8.2\%) [16]. In the United Kingdom, sodium intake is $3406 \mathrm{mg} /$ day, and the main sources of sodium are bread and grains (20.0\%), salted vegetables and fruits $(9.8 \%)$, miso soup (9.7\%), fish (9.5\%), and salt (9.5\%) [16]. The main sources of sodium in Australia are breads, cereal-based dishes, processed meat, and savory sauces [26]. The present study shows that the source of dietary sodium is different from other countries. The main source of dietary sodium in China is salt (69.2\%) added to food during meal preparation. The proportion of dietary sodium contributed by salt is higher than in countries such as Japan, the United Kingdom, and Australia [16,26]. Soy sauce $(8.2 \%)$, processed food $(6.0 \%)$, and chicken essence $(4.5 \%)$ are the next main contributors.

Salt is one of the main condiments in China, and the previous study shows that Chinese consumption of salt is the highest all over the world [27]. The present study shows that salt is the leading source of sodium, accounting for more than two-thirds (68.7\%) of total sodium intake. Thus, controlling salt consumption is essential for reducing sodium intake, and the strategies of reducing salt intake are effective in many countries. In 1979, Finland took action to reduce salt intake by developing reduced-salt food products with the food industry and raising general awareness on salt and health [28]. As a result, the prevalence of hypertension and mortality of stroke decreased [28,29]. The salt intake 
dropped from $9.5 \mathrm{~g}$ to $8.6 \mathrm{~g}$ in four years since the British government took measures to improve food processed with salt [30]. In addition, countries such as Canada [31], Japan [32], and America [33] carried out salt reduction activities. In recent years, salt reduction activities have been carried out to reduce salt intake, such as limiting excessive salt added to food during cooking a home-cooked meal and reducing sodium intake when eating out (restaurant and canteen). At the same time, it is possible to reduce the added salt in food by adding natural seasonings to the food, which can improve its taste.

It should be noted that dietary sodium contributed by flour products ranked third for adults from the north, accounting for $7.1 \%$ of total sodium intake. Salt is an important component of flour products, since it increases flour products' shelf-life and improves the taste [34]. Previous studies have shown that the amount of salt in bread from $397 \mathrm{mg} / 100 \mathrm{~g}$ bread in the United Kingdom to $1800 \mathrm{mg} / 100 \mathrm{~g}$ bread in Turkey [35]. Northern subjects consumed more sodium from flour products than southern subjects, which may be attributed to northern adults' preference for noodles and bread. A longitudinal study of Chinese adults found that the consumption of flour products in the northern area was more than twice that in the southern area [36]. Thus, for northerners, public health education should be implemented to raise awareness of the effects of sodium in flour products, which will help to reduce the total dietary sodium intake.

With the rapid development of the economy, the transformation from a traditional dietary pattern to a modern dietary pattern accelerated, and the consumption of processed food represented by high sodium and high energy was on the rise [37-40]. The present study shows that dietary sodium contributed by processed food in the economically developed urban areas is 3.3\%, higher than $1.6 \%$ in rural areas. This is consistent with the results of Mizehoun-Adissoda et al. [41]. The amount of dietary sodium contributed by processed food in rural areas is lower than that in urban areas, for the latter may be easier to access processed food than the former [42]. In recent years, urbanization has accelerated the Chinese market expansion of processed food [43], which has provided residents more opportunities to obtain processed food. Therefore, the total dietary sodium could be reduced by controlling sodium from processed food, and the department concerned should strengthen supervision over the labeling of sodium in processed food so that consumers can reasonably choose low-sodium food.

The young prefer modern food and processed food. The present study found that the sources of dietary sodium differ between age groups in both urban and rural subjects, and the amount of sodium contributed by processed food and animal food in the 18-49 years-old group was higher than in the elder age group. A study conducted in the US $(n=22852)$ also showed a gender difference in food sources of dietary sodium. Subjects aged 20-50 years old obtained a higher proportion of sodium from pizza, pasta, chicken, beef, and Mexican mixed dishes compared with subjects aged 50 years old and over [44]. In Spain, adolescents and adults consumed a higher proportion of dietary sodium from meat, processed meat products, and ready-to-eat meals than older people [45].

There were three limitations in this study. Firstly, we calculated the sodium provided by food according to the Chinese Food Composition Table. However, in the actual operation, since there was a lack of some kinds of processed food data in the Chinese Food Composition Table, and the composition of different brands of food may be different, we used similar foods to estimate the sodium content of such foods, which may be inaccurate for calculating dietary sodium intake. Secondly, the sodium contributed by eating out was calculated based on the food eaten at home, which could have led to an underestimation of total dietary sodium intake. A previous study showed that salt consumption provided by eating out is higher than that eating at home [46]. Thirdly, 24-h urinary sodium excretion is the gold standard for estimating sodium intake, but due to the large number of recruited adults in this study, the total dietary sodium was estimated from three consecutive days. The sodium results obtained in this study are higher than recalls combined with the household food weighing method instead of 24-h urinary sodium excretion; thus, the consumption of sodium may have been underestimated. 


\section{Conclusions}

In conclusion, controlling the dietary sodium intake is a challenging and relevant public health goal as the status of Chinese sodium intake is more than twice as much as the recommended consumption set by WHO. Overconsumption of sodium is positively related to adverse health outcomes, such as hypertension, so efforts to reduce sodium from diets must be enhanced. The data of this study show that salt is the main contributor to total sodium intake; thus, conducting "action on salt China" as well as strengthening health education are key goals for public health authorities to reduce sodium intake.

Author Contributions: The authors contributions were as follows: K.F. analysis the data and wrote the draft; Y.F. and Y.H. performed the surveys; Y.L. and Y.H. revised the manuscript. All authors approved the final manuscript. All authors have read and agreed to the published version of the manuscript.

Funding: This research was supported by The National Key Research and Development Program of China, Study on Attribution Burden of Risk Factors Related to Major Chronic Diseases (No. 2018YFC1315303). The China National Nutrition and Health Surveillance 2010-2012 was supported by the Special Fund for Health-Scientific Research in the Public Interest (No. 20120212) from the National Health and Family Planning Commission of the People's Republic of China.

Acknowledgments: We acknowledge all subjects and staff at Chinese National Nutrition and Health Surveillance (CNNHS) and the support from the related departments of 31 provinces, autonomous regions and municipalities.

Conflicts of Interest: All authors declared no conflict of interest.

\section{References}

1. World Health Organization. Guideline: Sodium Intake for Adults and Children; World Health Organization: Geneva, Switzerland, 2012.

2. Webb, M.; Fahimi, S.; Singh, G.M.; Khatibzadeh, S.; Micha, R.; Powles, J.; Mozaffarian, D. Cost effectiveness of a government supported policy strategy to decrease sodium intake: Global analysis across 183 nations. BMJ 2017, 356, i6699. [CrossRef] [PubMed]

3. Mente, A.; O’Donnell, M.J.; Rangarajan, S.; McQueen, M.J.; Poirier, P.; Wielgosz, A.; Morrison, H.; Li, W.; Wang, X.; Di, C.; et al. Association of urinary sodium and potassium excretion with blood pressure. N. Engl. J. Med. 2014, 371, 601-611. [CrossRef] [PubMed]

4. He, F.J.; MacGregor, G.A. Effect of modest salt reduction on blood pressure: A meta-analysis of randomized trials. Implications for public health. J. Hum. Hypertens. 2002, 16, 761-770. [CrossRef] [PubMed]

5. Poggio, R.; Gutierrez, L.; Matta, M.G.; Elorriaga, N.; Irazola, V.; Rubinstein, A. Daily sodium consumption and CVD mortality in the general population: Systematic review and meta-analysis of prospective studies. Public Health Nutr. 2015, 18, 695-704. [CrossRef]

6. Graudal, N.; Jurgens, G.; Baslund, B.; Alderman, M.H. Compared with usual sodium intake, low- and excessive-sodium diets are associated with increased mortality: A meta-analysis. Am. J. Hypertens. 2014, 27, 1129-1137. [CrossRef]

7. Strazzullo, P.; D’Elia, L.; Kandala, N.B.; Cappuccio, F.P. Salt intake, stroke, and cardiovascular disease: Meta-analysis of prospective studies. BMJ 2009, 339, b4567. [CrossRef]

8. He, F.J.; MacGregor, G.A. Fortnightly review: Beneficial effects of potassium. BMJ 2001, 323, 497-501. [CrossRef]

9. He, F.J.; MacGregor, G.A. Role of salt intake in prevention of cardiovascular disease: Controversies and challenges. Nat. Rev. Cardiol. 2018, 15, 371-377. [CrossRef]

10. He, Y.; Li, Y.; Yang, X.; Hemler, E.C.; Fang, Y.; Zhao, L.; Zhang, J.; Yang, Z.; Wang, Z.; He, L.; et al. The dietary transition and its association with cardiometabolic mortality among Chinese adults, 1982-2012: A cross-sectional population-based study. Lancet Diabetes Endocrinol. 2019, 7, 540-548. [CrossRef]

11. Collaborators, G.B.D.C.o.D. Global, regional, and national age-sex-specific mortality for 282 causes of death in 195 countries and territories, 1980-2017: A systematic analysis for the Global Burden of Disease Study 2017. Lancet 2018, 392, 1736-1788. [CrossRef]

12. Harnack, L.J.; Cogswell, M.E.; Shikany, J.M.; Gardner, C.D.; Gillespie, C.; Loria, C.M.; Zhou, X.; Yuan, K.; Steffen, L.M. Sources of Sodium in US Adults From 3 Geographic Regions. Circulation 2017, 135, 1775-1783. [CrossRef] 
13. Colin-Ramirez, E.; Espinosa-Cuevas, A.; Miranda-Alatriste, P.V.; Tovar-Villegas, V.I.; Arcand, J.; Correa-Rotter, R. Food Sources of Sodium Intake in an Adult Mexican Population: A Sub-Analysis of the SALMEX Study. Nutrients 2017, 9, 810. [CrossRef]

14. Ravi, S.; Bermudez, O.I.; Harivanzan, V.; Kenneth Chui, K.H.; Vasudevan, P.; Must, A.; Thanikachalam, S.; Thanikachalam, M. Sodium Intake, Blood Pressure, and Dietary Sources of Sodium in an Adult South Indian Population. Ann. Glob. Health 2016, 82, 234-242. [CrossRef] [PubMed]

15. Asakura, K.; Uechi, K.; Masayasu, S.; Sasaki, S. Sodium sources in the Japanese diet: Difference between generations and sexes. Public Health Nutr. 2016, 19, 2011-2023. [CrossRef] [PubMed]

16. Anderson, C.A.; Appel, L.J.; Okuda, N.; Brown, I.J.; Chan, Q.; Zhao, L.; Ueshima, H.; Kesteloot, H.; Miura, K.; Curb, J.D.; et al. Dietary sources of sodium in China, Japan, the United Kingdom, and the United States, women and men aged 40 to 59 years: The INTERMAP study. J. Am. Diet. Assoc. 2010, 110, 736-745. [CrossRef] [PubMed]

17. Appel, L.J.; Foti, K. Sources of Dietary Sodium: Implications for Patients, Physicians, and Policy. Circulation 2017, 135, 1784-1787. [CrossRef]

18. Zhao, L.; Ma, G.; Piao, J.; Zhang, J.; Yu, D.; He, Y.; Huo, J.; Hu, X.; Yang, Z.; Yang, X. Scheme of the 2010-2012 Chinese nutrition and health surveillance. Zhonghua Yu Fang Yi Xue Za Zhi 2016, 50, 204-207. [CrossRef]

19. Yang, Y.X. Chinese Food Composition Table, 2nd ed.; Peking University Medical Press: Beijing, China, 2009; ISBN 978-7-81116-727-6.

20. Chinese Nutrition Society. Chinese Dietary Reference intakes (2013); Science Press: Beijing, China, 2014; ISBN 978-7-03-041401-4.

21. Rehm, C.D.; Penalvo, J.L.; Afshin, A.; Mozaffarian, D. Dietary Intake Among US Adults, 1999-2012. JAMA 2016, 315, 2542-2553. [CrossRef]

22. Hipgrave, D.B.; Chang, S.; Li, X.; Wu, Y. Salt and Sodium Intake in China. JAMA 2016, 315, 703-705. [CrossRef]

23. Mozaffarian, D.; Fahimi, S.; Singh, G.M.; Micha, R.; Khatibzadeh, S.; Engell, R.E.; Lim, S.; Danaei, G.; Ezzati, M.; Powles, J.; et al. Global sodium consumption and death from cardiovascular causes. N. Engl. J. Med. 2014, 371, 624-634. [CrossRef]

24. Graudal, N.; Hubeck-Graudal, T.; Jurgens, G.; Taylor, R.S. Dose-response relation between dietary sodium and blood pressure: A meta-regression analysis of 133 randomized controlled trials. Am. J. Clin. Nutr. 2019, 109, 1273-1278. [CrossRef] [PubMed]

25. Lim, S.S.; Vos, T.; Flaxman, A.D.; Danaei, G.; Shibuya, K.; Adair-Rohani, H.; Amann, M.; Anderson, H.R.; Andrews, K.G.; Aryee, M.; et al. A comparative risk assessment of burden of disease and injury attributable to 67 risk factors and risk factor clusters in 21 regions, 1990-2010: A systematic analysis for the Global Burden of Disease Study 2010. Lancet 2012, 380, 2224-2260. [CrossRef]

26. Grimes, C.A.; Szymlek-Gay, E.A.; Nowson, C.A. Trends in Dietary Sodium from Food Sources in Australian Children and Adolescents from 2007 to 2011/12. J. Acad. Nutr. Diet. 2018, 118, 1183-1195.e6. [CrossRef] [PubMed]

27. Tan, M.; He, F.J.; Wang, C.; MacGregor, G.A. Twenty-Four-Hour Urinary Sodium and Potassium Excretion in China: A Systematic Review and Meta-Analysis. J. Am. Heart Assoc. 2019, 8, e012923. [CrossRef]

28. Laatikainen, T.; Pietinen, P.; Valsta, L.; Sundvall, J.; Reinivuo, H.; Tuomilehto, J. Sodium in the Finnish diet: 20-year trends in urinary sodium excretion among the adult population. Eur. J. Clin. Nutr. 2006, 60, 965-970. [CrossRef]

29. Pietinen, P.; Paturi, M.; Reinivuo, H.; Tapanainen, H.; Valsta, L.M. FINDIET 2007 Survey: Energy and nutrient intakes. Public Health Nutr. 2010, 13, 920-924. [CrossRef]

30. Millett, C.; Laverty, A.A.; Stylianou, N.; Bibbins-Domingo, K.; Pape, U.J. Impacts of a national strategy to reduce population salt intake in England: Serial cross sectional study. PLoS ONE 2012, 7, e29836. [CrossRef]

31. McLaren, L.; Heidinger, S.; Dutton, D.J.; Tarasuk, V.; Campbell, N.R. A repeated cross-sectional study of socio-economic inequities in dietary sodium consumption among Canadian adults: Implications for national sodium reduction strategies. Int. J. Equity Health 2014, 13, 44. [CrossRef]

32. Ikeda, N.; Takimoto, H.; Imai, S.; Miyachi, M.; Nishi, N. Data Resource Profile: The Japan National Health and Nutrition Survey (NHNS). Int. J. Epidemiol. 2015, 44, 1842-1849. [CrossRef] 
33. Cogswell, M.E.; Zhang, Z.; Carriquiry, A.L.; Gunn, J.P.; Kuklina, E.V.; Saydah, S.H.; Yang, Q.; Moshfegh, A.J. Sodium and potassium intakes among US adults: NHANES 2003-2008. Am. J. Clin. Nutr. 2012, 96, 647-657. [CrossRef]

34. Belz, M.C.; Ryan, L.A.; Arendt, E.K. The impact of salt reduction in bread: A review. Crit. Rev. Food Sci. Nutr. 2012, 52, 514-524. [CrossRef] [PubMed]

35. Quilez, J.; Salas-Salvado, J. Salt in bread in Europe: Potential benefits of reduction. Nutr. Rev. 2012, 70, 666-678. [CrossRef] [PubMed]

36. Huang, L.; Wang, H.; Wang, Z.; Zhang, J.; Zhang, B.; Ding, G. Regional Disparities in the Association between Cereal Consumption and Metabolic Syndrome: Results from the China Health and Nutrition Survey. Nutrients 2019, 11, 764. [CrossRef]

37. Wang, Y.; Wang, L.; Xue, H.; Qu, W. A Review of the Growth of the Fast Food Industry in China and Its Potential Impact on Obesity. Int. J. Environ. Res. Public Health 2016, 13, 1112. [CrossRef] [PubMed]

38. Pan, A.; Malik, V.S.; Hu, F.B. Exporting diabetes mellitus to Asia: The impact of Western-style fast food. Circulation 2012, 126, 163-165. [CrossRef] [PubMed]

39. Zhao, Y.; Wang, L.; Xue, H.; Wang, H.; Wang, Y. Fast food consumption and its associations with obesity and hypertension among children: Results from the baseline data of the Childhood Obesity Study in China Mega-cities. BMC Public Health 2017, 17, 933. [CrossRef]

40. Rehm, C.D.; Drewnowski, A. Trends in Consumption of Solid Fats, Added Sugars, Sodium, Sugar-Sweetened Beverages, and Fruit from Fast Food Restaurants and by Fast Food Restaurant Type among US Children, 2003-2010. Nutrients 2016, 8, 804. [CrossRef]

41. Mizehoun-Adissoda, C.; Houinato, D.; Houehanou, C.; Chianea, T.; Dalmay, F.; Bigot, A.; Aboyans, V.; Preux, P.M.; Bovet, P.; Desport, J.C. Dietary sodium and potassium intakes: Data from urban and rural areas. Nutrition 2017, 33, 35-41. [CrossRef]

42. Sodjinou, R.; Agueh, V.; Fayomi, B.; Delisle, H. Dietary patterns of urban adults in Benin: Relationship with overall diet quality and socio-demographic characteristics. Eur. J. Clin. Nutr. 2009, 63, 222-228. [CrossRef]

43. Zhang, Q.; Chen, X.; Liu, Z.; Varma, D.S.; Wan, R.; Zhao, S. Diet diversity and nutritional status among adults in southwest China. PLoS ONE 2017, 12, e0172406. [CrossRef]

44. Drewnowski, A.; Rehm, C.D. Sodium intakes of US children and adults from foods and beverages by location of origin and by specific food source. Nutrients 2013, 5, 1840-1855. [CrossRef] [PubMed]

45. Partearroyo, T.; Samaniego-Vaesken, M.; Ruiz, E.; Aranceta-Bartrina, J.; Gil, Á.; González-Gross, M.; Ortega, R.M.; Serra-Majem, L.; Varela-Moreiras, G. Sodium Intake from Foods Exceeds Recommended Limits in the Spanish Population: The ANIBES Study. Nutrients 2019, 11, 2451. [CrossRef] [PubMed]

46. Zang, J.; Luo, B.; Wang, Y.; Zhu, Z.; Wang, Z.; He, X.; Wang, W.; Guo, Y.; Chen, X.; Wang, C.; et al. Eating Out-of-Home in Adult Residents in Shanghai and the Nutritional Differences among Dining Places. Nutrients 2018, 10, 951. [CrossRef] [PubMed]

(C) 2020 by the authors. Licensee MDPI, Basel, Switzerland. This article is an open access article distributed under the terms and conditions of the Creative Commons Attribution (CC BY) license (http://creativecommons.org/licenses/by/4.0/). 